\title{
Residential architecture and developmentalism: a place and two contexts
}

\author{
L. Etxepare \\ Department of Architecture, University of the Basque Country, Spain
}

\begin{abstract}
The residential architecture of the 60s adopted specific features all over Europe, and it is the most faithful testimony of the developmental period undergone by the West at the start of the last third of the 20th century. We present two representative case-studies that show the character adopted by developmental architecture in a place - the Basque Country - the analysis of which proves the influence of two different contexts. The first one is located in the Spanish part of the Basque Country. It is the case of the Bidebieta twelve blocks of flats, in Donostia-San Sebastian, designed by Luis Alustiza (1964). They obey an architectural type incipient in the Basque Country at that time: the tower block. The second case is located in Bayonne, France, and it is made up of seven blocks of apartments that were designed by Marcel Breuer (1967). Both of them reflect faithfully the specific characteristics of the construction and town planning prevailing in both states at the time, clearly diverging in matters such as the housing typology, the structural systems and the prefabrication.

Keywords: Basque Country, residential architecture, developmentalism, Donostia-San Sebastian, Bayonne.

1 Introduction

Residential architecture of the sixties constitutes the most faithful testimony of the developmental period that Europe lived at the onset of the last third of the $20^{\text {th }}$ century. The revolution experimented by the construction of subsidized collective housing involved such urban, typological and constructive innovations that the resulting architecture required more time than ever to be understood and finally to be positively valued by society.
\end{abstract}


Two cases are presented that show the character adopted by Architecture during this developmental period in a place - the Basque Country - the analysis of which demonstrates the influence of two diverse contexts: the Bidebieta Towers (1964), situated in Donostia, Spain, and the Hautes de Sainte-Croix Z.U.P. (priority zones for urban development) blocks of houses (1965), situated in Bayonne, France. Both buildings, dating from the same period, are the same distance from the Spanish-French border. They show faithfully the specific characteristics adopted by the developmental residential construction on both sides of the border during the $20^{\text {th }}$ century, which are divergent in matters such as urban planning, typology and constructive systems.

\section{The demographic boom}

During the 60s and 70s, the population in Gipuzkoa - a Basque province in Spain - duplicated its rate of growth as compared to that of the previous decades: $27 \%$ from 1950 to 1960 , and 32\% from 1960 to 1970 , reaching 625,000 inhabitants in 1970. Said growth was more obvious in its capital, Donostia, since it is the home to one quarter of the population. The demographic evolution of the population in Bayonne - administrative office of the French Basque Country equaled that of France. Once the population growth had been recovered after the two great wars, the population experienced a sharp increase: from the mid 50's to the mid 70 's it grew by $30 \%$, reaching its zenith in 1975 , with 43,000 inhabitants.

\section{Two ways of urban planning management in public housing}

\subsection{Development areas and partial plans}

The Development Plan (1964-1967) that was started by the Spanish dictatorial government and promoted by the Industry and the third sector of the economy, kept the Ministry of Housing relegated for some years. This ministry did not recover its primacy until the National Housing Plan (1961-1976) was implemented. Under said plan the construction of 4 million dwellings was programmed and the unbounded developmental criteria in the residential environment was put into practice. The 1956 Land Law was as influential as the housing plan. Once the lands had been classified, said law established the Systems of Performance to be applied in each case: the Provincial Plan, the Urban Development Plan and the Partial Plan. It also established the model of the development area, an instrument for the development of the city that results from joining several plots, and that has the capacity of turning the reserved land into urban land [1]. The planning model called Partial Plan is the one to establish the urban characteristics of the development areas: alignments, heights, volumes and uses. Partial plans and development areas were the main tools for the construction of dwellings during this developmental period in Spain. 


\subsection{Priority Zones for Urban Development (Z.U.P.)}

Faced with the growing demand of housing in all the cities in France, the Journal Officiel de la République Française (the Official Gazette of the French Republic) provided, in January 1959, the administrative procedure for urban planning by means of which the minister of construction could assign Priority Zones for Urban Development (Z.U.P) in those municipalities where housing construction was urgent [2]. The zone had to span an area large enough for the construction of at least five hundred homes, as well as annexed facilities and equipments.

The dossier that was required for the designation of a Z.U.P. had to include a series of graphic documents and writings, the ratification of the local municipal Council and a first report stating the surface, the expected number of homes, the equipments, roads and infrastructures. After obtaining the approval of the Ministry of Construction, the Chief-architect also had to be appointed. This type of measure required that the purchase of the land be made as soon as possible, and therefore the process of expropriation was generally initiated, ordering the Declaration of Public Interest of the lands. The institution in charge of this, generally an Economic Company of mixed nature, would manage the expropriations and be in charge of the construction. The administrative procedure, through which a Z.U.P. was assigned, was the main instrument for planning subsidized housing used in France during the developmental period. Between 1959 and 1967, 195 Z.U.P. were built in France, containing more than 800,000 homes.

\section{Two cases}

\subsection{Donostia: the Bidebieta Towers (1964)}

The Bidebieda Towers, in Donostia-San Sebastian, were promoted by the Instituto Nacional de la Vivienda (National Institute of Housing). They were planned by the Arquitect Luis Alustiza and built by the Obra Sindical del Hogar y Arquitectura, from 1964 onwards. They comprise 732 homes, which after some years would lodge three thousand people, nearly $2 \%$ of the population in the city.

In 1961, the Instituto Nacional de la Vivienda implemented the expropriation Project and the partial plan for the formation of a development area conceived for the construction of low cost state-subsidized housing. The project planned a free arrangement of the towers, dispersed in a garden and joined by means of a road, as if they were disperse milestones. One can appreciate an obvious influence of the urban principles of Le Corbusier, especially those used in Ville Radieuse.

The towers designed by Alustiza are fifteen storeys high and they have an Xshaped plan. Each arm of the X contains a dwelling, the staircase being located in the central axis. The layout of each apartment is composed of an entrance hall and living room, a kitchen and three bedrooms. The basement situated under the 
access plan consists of a rigid concrete box that retains the perimetral ground. An external staircase is situated next to the concrete box and it rises from the street level to the mezzanine, covered but open, like a porch.

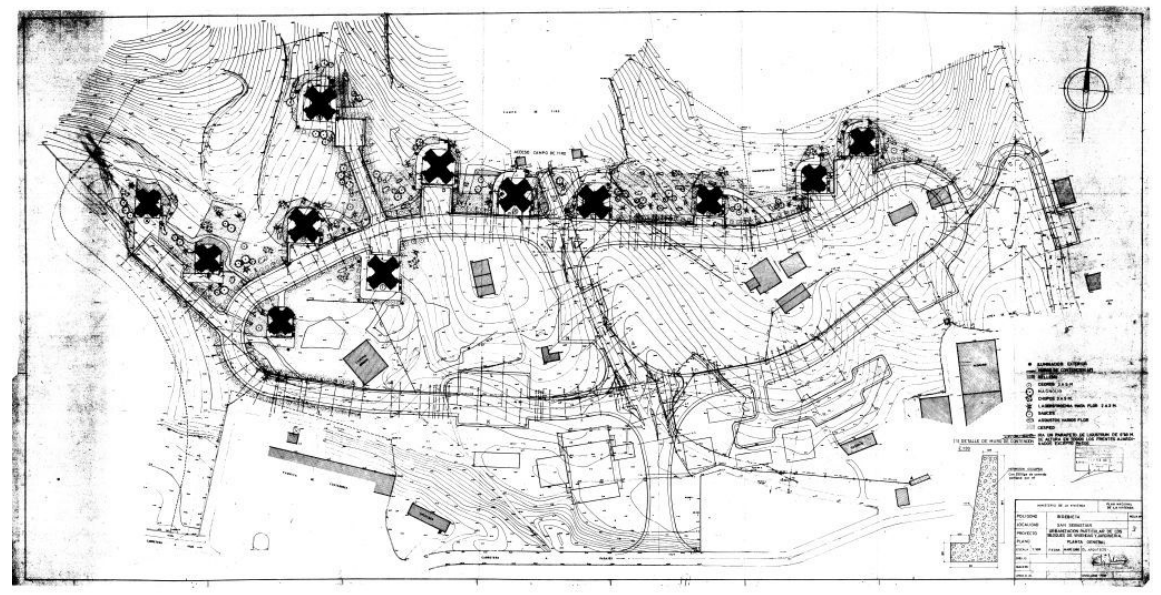

Figure 1: Arrangement plan of the Bidebieta Towers.

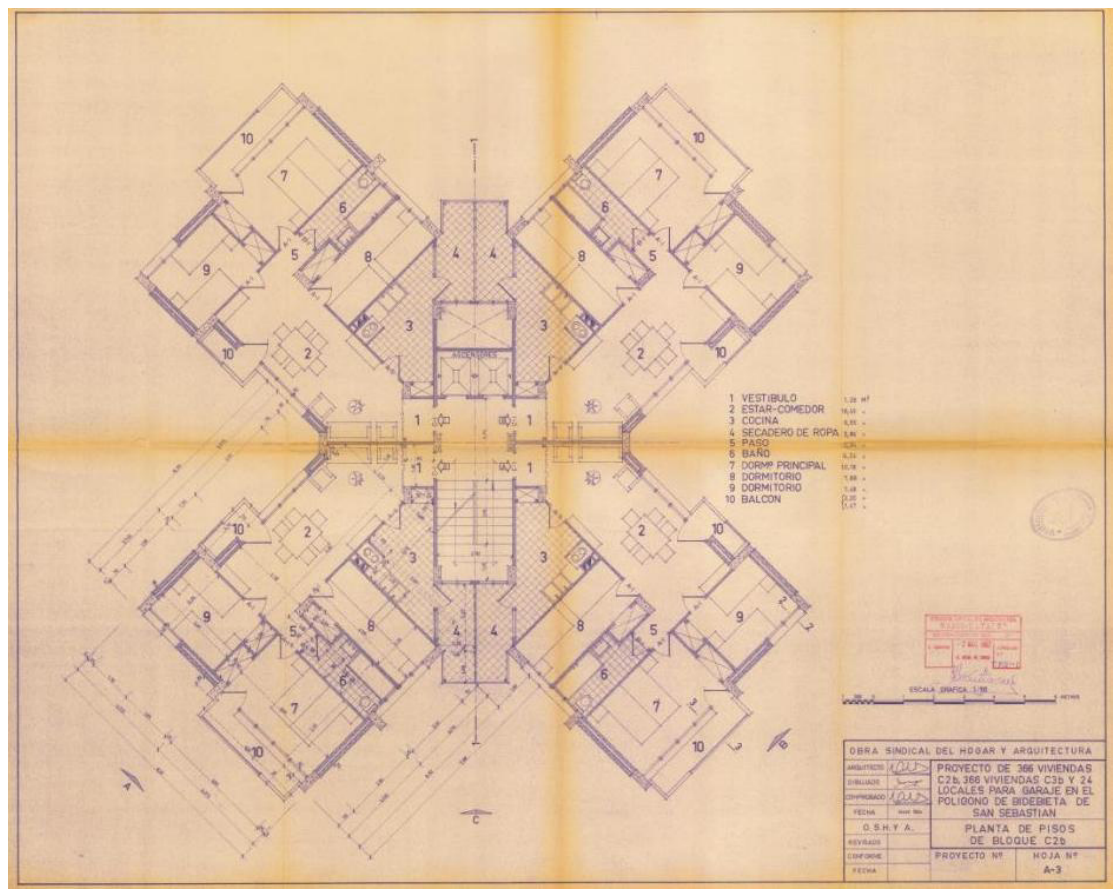

Figure 2: Plan type of the Bidebieta Towers. 
Although the initial design had planned a reinforced concrete frame, the construction company chose a metal frame adducing that it was cheaper. The new structure planned the use of concrete only up to the ceiling of the basement, continuing from there upwards with a rolled-steel frame. Due to the size of the building and to the effects of the action of the wind, the structure would be reinforced with triangular trusses [3].

To the end of providing rigidity to the foundation concrete slab, they chose to give it a mixed composition, using a metal formwork and a layer of in-situ poured concrete. In this manner, the beams attained also a mixed nature, as they were joined to the concrete layer through welded spirals that served as connectors in the upper part. The applicable standards at the time on mixed beams, DIN-4039, as well as the instructions gathered in the North American publication Composite-Construction in Steel and Concrete were taken into consideration. The structure was built on reinforced concrete piles that had a diameter of $630 \mathrm{~mm}$ and were constructed in situ.

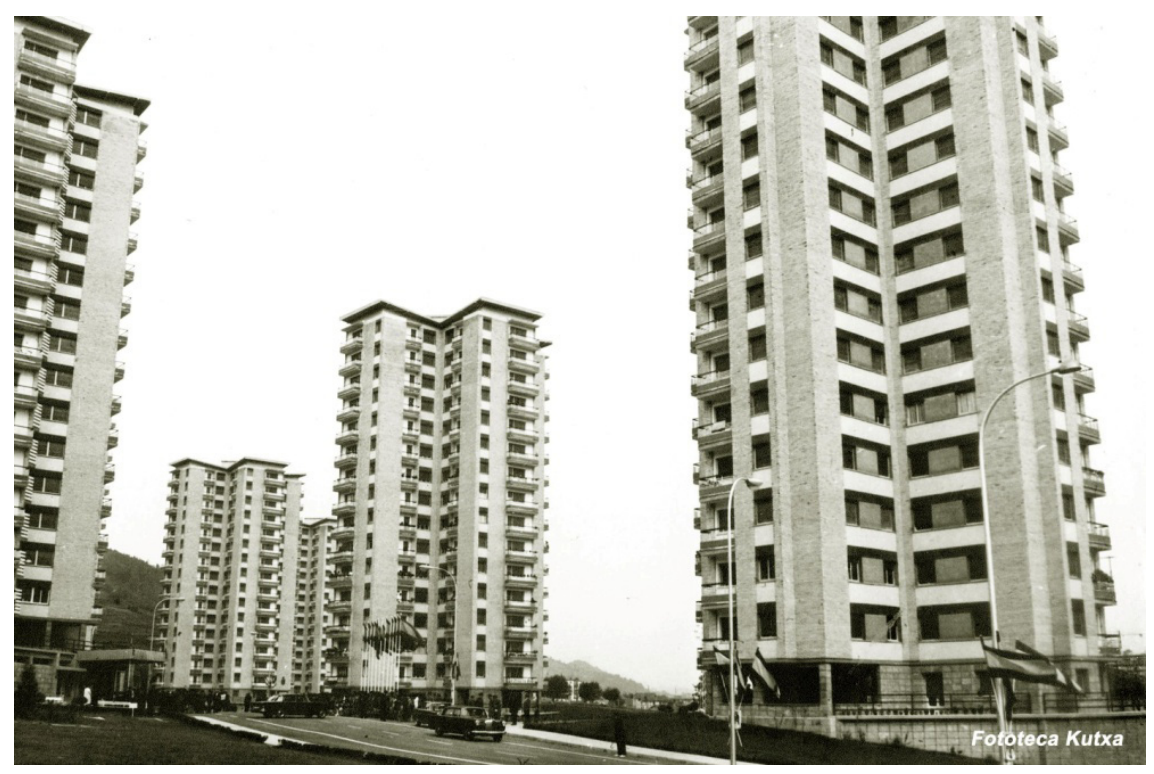

Figure 3: Photograph of the Bidebieta Towers.

The facades, constructed with masonry techniques, were solved with a double ceramic sheeting, and a gresite cladding. No insulation was inserted between both ceramic sheets: cold temperatures and energy saving were minor matters, and it was only from the 1973 oil crisis that the use of insulating materials became more common. The water supply to the houses would be done by gravity, installing two big water tanks under the roof. The water would reach these tanks, driven upwards by a water pump, and it would descend to each one 
of the homes by the force of gravity. The heating and the water heating would be electrical.

\subsection{Bayonne: The Z.U.P. of Hautes de Sainte-Croix (1967)}

On the 12 December 1963, after the City Hall had received an application, a decree of the Board of Ministers was published to the end of appointing a priority zone for urban development at the Hautes de Sainte-Croix, located on the Adour river in Bayonne. The appointment of Marcel Breuer as Chiefarchitect in charge of designing the project was approved on the $21^{\text {st }}$ September 1964.

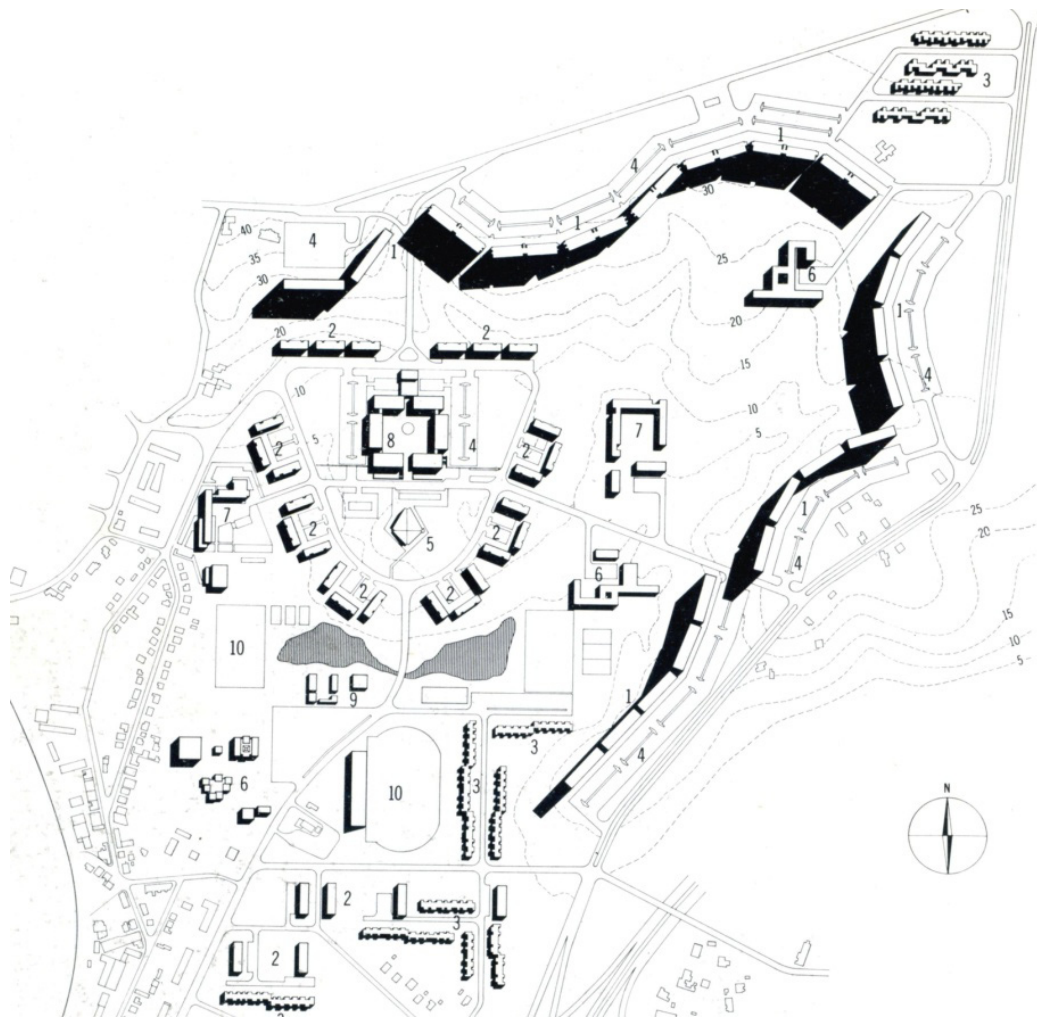

Figure 4: Arrangement Plan of the Hautes de Sainte-Croix Z.U.P.

The blocks are 13 storeys high and they adopt the form of a slab and, even if at first the construction of 14 blocks was planned, finally only one half of them were built. Besides these blocks, the construction of a public square was also conceived with another supplementary housing programme, as well as shops, a youth house, a social centre and a post office.

The legislation that controlled the design of French social housing was extremely strict [4]. The French experience of the war, with insalubrious 
dwellings, plagued with blackouts and elevator shut downs, imposed a series of specific requirements in the course of time in all those apartments with more than one bedroom: cross ventilation by means of windows to two facades, kitchens with street-orientated windows, a space for hanging the clothes and ventilation shunts for the bathrooms as well as a strict maintenance of the elevation systems.

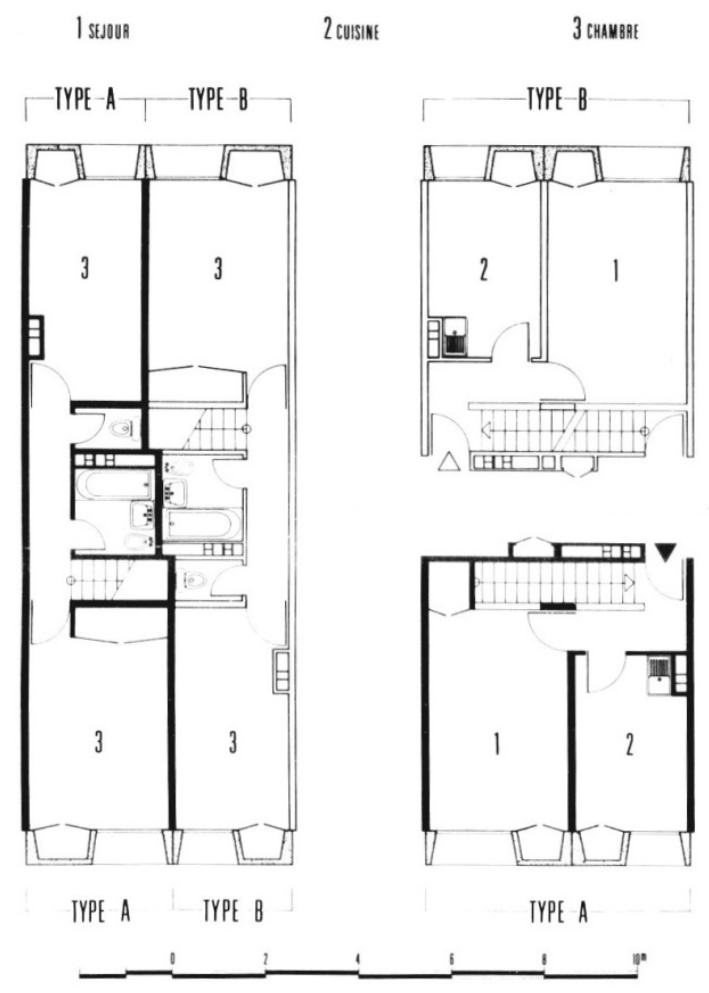

Figure 5: $\quad$ Organization of the Z.U.P. dwellings.

Breuer took up again some concepts he had already proposed in the decade of the twenties: alternated floors and duplex-type dwellings, with access to the apartments by means of elevators and corridors that were only provided once every 3 floors. Thus, on floors 2, 5, 8 and 11, a central passage goes along the building in the longitudinal direction, giving access to four models of apartments on each side of the corridor: apartments A and B, with two bedrooms and juxtaposed around the central corridor, that have a day programme on the entry floor and take up one half of the space that is at the end of the building, and a programme of bedrooms that occupies the whole lower bay; apartments $\mathrm{C}$ and $\mathrm{D}$, that only have an entrance hall and a stairway on the entry floor and that develop all their programme on the upper floor. 
The construction technique used to raise the structure adapted a "tunnelformwork" industrial technique to the complex interior shapes of the building. Metal frames forming a casting tunnel that rested on the foundation concrete slab of the lower floor were fitted in; after the concrete had been poured and set, they were dismantled and rebuilt on the new concrete slab, optimizing the time limits and economizing labour.

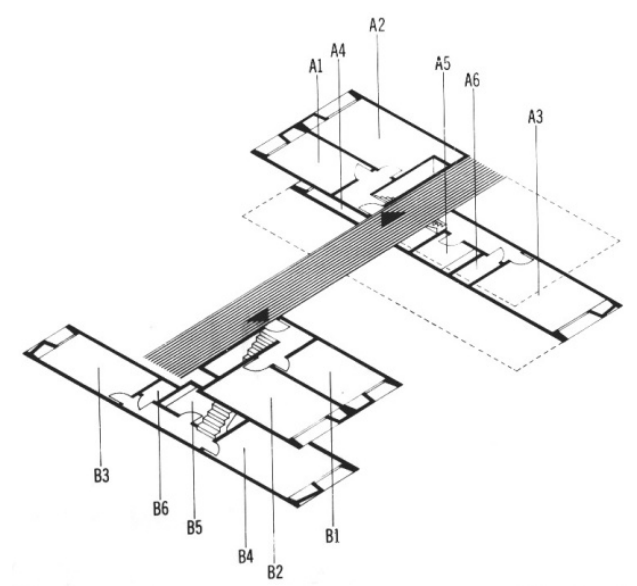

Figure 6: Detail of the Z.U.P. duplex apartments.

The enclosure was solved with the use of prefabricated panels, to which Breuer frequently resorted to because he valued the sculptural possibilities of the product. The casting possibilities of precast concrete when giving shape to a window, a screen or a lattice, made this concrete to be an irresistible and also economical material, thanks to the activity and the inventiveness that the production of prefabricated elements experimented at that time on both sides of the Atlantic. The chemical treatments and surface finishings would furthermore make the panels durable and resistant.

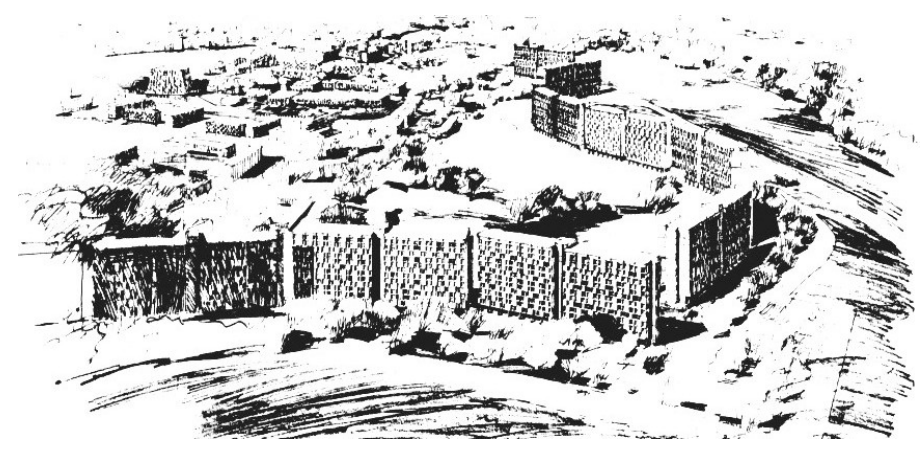

Figure 7: Drawing of the Z.U.P. blocks. 
The organisation of the panels was imposed by the tridimensional web used to juxtapose the apartments: modules with a height of 2.66 metres and with alternated widths of 3.14 and 2.56 metres, forming a regular web, enlivened by a variable organisation of the openings, and adopting the appearance of a honeycomb, whose most expressive element consists in the splayed appearance of the window that is recessed in relation to the external facing, causing deep shades that give the facade an expressionist character.

\section{Comparative aspects}

\subsection{The role of the institutions}

In spite of the strict control of the Spanish government, part of the new urban competences were diverted to the provincial authorities. The development of Gipuzkoa would follow for years the guidelines of the Plan de Ordenación Territorial de Gipuzkoa (Gipuzkoa Development Plan, 1944), a fruit of the collaboration between the Dirección General de Arquitectura (Central Government Department of Architecture) and the provincial institutions [5]. The planning management was directed by the Oficinas Provinciales de Arquitectura $y$ Urbanismo (Provincial Offices of Architecture and Urbanism) that were headed by architects trusted by the Central Government. The Gipuzkoa Provincial Office interceded so that the administration's commissions would be assigned to trustworthy professionals. All of this explains, together with the influence and the importance of local architects' associations, why the responsibility to design the Bidebieta Towers was assigned to Luis Alustiza, an architect from San Sebastian.

On the contrary, the professional group of architects in France was not as strong as in Spain due to the fact, among other things, that they had fewer professional powers and functions. In the French Basque Country there were fewer architects and they had fewer professional responsibilities, and the French local administration did not feel any commitment towards a group that had a lower social and economic influence than that of the architects on the other side of the border.

Furthermore, the appointment of the Chief Architect had to be approved by the French Cabinet of Ministers, with the result that the election of the Chief Architect was taken at a very high political level. André Malraux, a writer and political activist who was known as possessing the greatest knowledge and passion for the Architecture of the Modern Movement was at that time member of the Cabinet of Ministers of Charles de Gaulle's Government, holding the office of Minister of Culture. It was Malraux who approved with pleasure the appointment of Breuer that had been proposed by Max Ernst, director of the B.E.R.U. (Bureau d'Etudes et de Réalisations Urbaines, Bureau of Studies and of Urban Executions), an office that planned the programme of equipments for the Hautes de Sainte-Croix Z.U.P. 


\subsection{The programming of the equipments and their execution}

The study of collective equipments for the future Z.U.P., drawn up by the B.E.R.U., would serve as a general framework for the studies of area development. The programme was really ambitious: the area would have four primary education schools, two secondary schools and one dining hall; two sports centres; a programme providing medical and social care, with consultation for children and a dispensary against tuberculosis; a space assigned to social centres, a cultural centre and a space for young people; administrative equipment such as a post office, a community office, and a police station; and finally a Catholic church, including community facilities for meetings and catechesis [6].

This generosity of means is in deep contrast with the Bidebieta-Donostia equipment programme, because the facilities and equipments provided for the latter were not only less ambitious but their construction and achievement were left halfway. The complementary services needed by the neighbours, whether school, commercial, sports or spiritual type of services, would be developed in the different constructive stages of the Development Area. However, even if the partial Plan took into consideration complementary social programmes, the construction of the community facilities and equipments was left unfinished. In the developing Spain of the sixties, quite a few schools, national health clinics and churches were left unconstructed for the sake of economic feasibility.

\subsection{The building type and the construction techniques}

The Bidebieta Towers are the result of a deep typological research the outcome of which has been their great programmatic rigour and architectonic ambition. They have been constructed, undoubtedly, with constructive systems that were conventional at that time. Spain was devoid of an industrial tradition until the 20th century was half through, and therefore the prefabrication industry would not be established until the seventies. For this reason the Bidebieta project proposed at first a reinforced concrete frame structure and unidirectional slabs built in situ. The fact that the towers were finally erected with a steel structure means an exception to the conventional constructive systems of the time.

The Hautes de Sainte-Croix blocks adopted a modular building type based on the piling of a prismatic and flexible organizational unit in its interior layout [7]. It is a complex exercise, the result of which is a residential tablet crossed by inner alleys that also draws inspiration from Le Corbusier's Unités d'habitation. In postwar France, during the reconstruction of the country (1945-1960), architects and engineers, sponsored by the State, devised large-scale prefabrication procedures. Powerful construction companies, and also the Modern Movement, made a common cause in favour of the parallel progress of architecture and technique. A consequence of this all was the use of tunnel-forms for the construction of the concrete slabs, as well as the choice of the prefabricated panels for the cladding. 


\section{Conclusions}

The urban planning, the typological research and the constructive and structural systems used in the construction of subsidized housing in the Basque Country during the developmental period are strongly subjected to the traditions and divergent legislations of the two States where the Basque provinces are situated. In the Spanish context, the programming of the subsidized equipments concerning dwellings was less important and it was not always carried out; in France, however, it was the object of exhaustive programming, fulfilment and following-up by the State.

In the context shown by the Bidebieta Towers, we can affirm that the construction of the residential block did not imply the incorporation of new constructive systems. The novelty as regards the residential type did not come together with other innovations in the technical scope. On the contrary, the Bayonne Z.U.P. is a faithful reflection of the evolution undergone by the constructive systems and the planning from the moment of the reconstruction of France after World War II. This evolution can be seen in the research undertaken around the building type and, especially, in the technical systematization.

\section{References}

[1] Solà-Morales i Rubió, M., Las formas de crecimiento urbano. Edicions de la Universitat Politècnica de Catalunya: Barcelona, 1997.

[2] Journal Officiel de la Republique Francaise. Decree number 58-1464 of 31 December 1958, pp. 269, 4 January 1959.

[3] Alustiza, L., Proyecto de 732 viviendas y 24 locales para garajes. Euskadiko Artxibategi Orokorra (General Archive of Euskadi). VitoriaGasteiz. 1964.

[4] Gatje, R.F., Marcel Breuer. A memoir. The Monacelli Press: New York, 2000.

[5] Martín Ramos, A., Gipuzkoa urbana: nueve pautas. Gipuzkoako Foru Aldundia: Donostia-San Sebastián, 2008.

[6] Breuer, M., ZUP BAYONNE, Baiona eta Euskal Herriko artxibo gunea (Departamental archives, Pole of Bayonne and of the Basque Country). Baiona-Bayonne. 1965.

[7] Archives of American Art, Smithsonian Institution. Marcel Breuer papers, Series 8: Project files - Collections on line. www.aaa.si.edu/ collectionsonline/breumarc 